\title{
Knowledge management processes at St Paul's University Library in Kenya
}

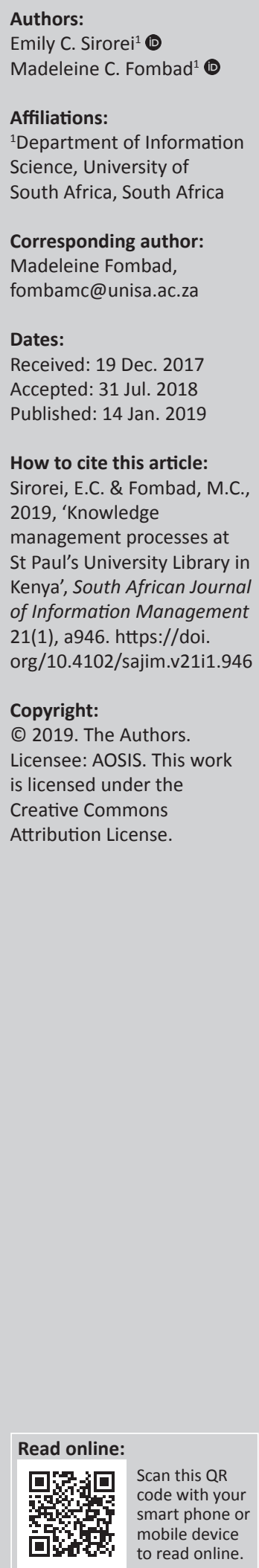

Background: Given the changes in society resulting from the explosion of information and knowledge in a knowledge economy, academic libraries are becoming an integral part of the knowledge system, and knowledge management is recognised as a vital process in academic libraries. The success of academic libraries in the competitive and challenging knowledge environment depends on their ability to utilise information and knowledge to meet the needs of the academic community.

Objectives: This article investigates knowledge management processes at St Paul's University Library in Kenya and suggests ways in which knowledge management processes may be enhanced.

Method: A qualitative research approach and a case study research design have been adopted. Out of the 50 target population, only 32 were successfully interviewed to the point of saturation, and the data were analysed using content analysis.

Results: The findings revealed that knowledge management processes were utilised at St Paul's University Library, albeit to varying degrees, and the knowledge management processes were not formalised.

Conclusion: The article recommends that knowledge management processes should be formally incorporated at academic libraries in Kenya. A formal knowledge management process at St Paul's University Library may be realised through an institutionalised written knowledge management policy with leadership buy-in. A future quantitative survey of knowledge management processes in all academic libraries in Kenya is suggested.

\section{Introduction}

The evolution of the information and knowledge society has altered the ways in which services are provided in academic libraries, thus making knowledge management an imperative (Koloniari \& Fassoulis 2017; Mavodza \& Ngulube 2011). Knowledge management in academic libraries will promote job effectiveness and make the library relevant to its parent institution, thereby offering the opportunity to expand the role of libraries in areas where librarians have had little impact in (Ongus et al. 2015; Thanuskodi 2010; Wen 2005). Academic libraries have long enjoyed their status as the 'heart of the university'. They are established to support teaching, learning, research activities of the parent institution and the development of a culture of sharing and imparting knowledge to fulfil the mission and objectives of their parent institutions (Jantz 2001:3).

Academic libraries are conscious of the role and benefits of knowledge management not only for library performance, but also for enhancing the organisational and competitive performance and future career options of the library and information profession (Islam, Agarwal \& Ikeda 2015; Islam, Siddike, Nowrin \& Naznin 2015; Koloniari \& Fassoulis 2017). Notwithstanding, there is a lack of implementation and lack of clarity on fundamental knowledge management issues in academic libraries. Only 34\% of the university libraries in India are implementing knowledge management in their libraries (Rao 2016). A study on knowledge management in Romanian academic libraries revealed a deep awareness of the importance of knowledge management application in libraries but small progress in its effective implementation within the academic libraries (Madge 2017). There is also still a dearth of research on knowledge management in academic libraries from an African perspective. Jain (2007), Wamundila (2008) and Mavodza and Ngulube (2011), for example, focused on the application and implementation of knowledge management with little emphasis on the knowledge management processes.

Note: This article is partially based on the author's thesis for the degree of Master's in Information Science at the University of South Africa, South Africa, with supervisorProf. M.C. Fombad, received June 2017, available here: http://uir.unisa.ac.za/bitstream/handle/10500/22826/ dissertation_sirorei_e.pdf?isAllowed $=y \&$ sequence $=1$ 
Although Kenyan universities are considered the core of knowledge creation, they are still lagging behind in the adoption and use of knowledge management. Studies on knowledge management in academic libraries in Kenya are limited, and the level of awareness of the concept of knowledge management is superficial (Anduvare 2015; Gichuhi 2015; Odero \& Ngeno 2009; Nyakenyanya 2013; Nyalwal 2015; Ogalo 2012; Wamalwa \& Omallah 2016).

St Paul's University is a Christian university located in Limuru, Kenya. It is one of the country's 14 chartered universities. The mission of the university is to impart knowledge, skills and values through creative methods of education, research and Christian spiritual formation. The library strives to support the aggressive research efforts of staff and students through the generation, retention, storage and sharing of information and knowledge. There is no documented study on knowledge management processes in St Paul's Library. Knowledge management practices in Kenya have extended to functional business units and international organisations (Mosoti \& Masheka 2010:129). The Kenyan Universities Act No. 42 of 2012 provided for the development of university education, and the establishment, accreditation and governance of universities in Kenya. There are 48 universities operating in Kenya. This includes 22 public universities, 14 chartered private universities and 14 universities with letter of interim authority (the Commission for University Education report, 2016). This is a well-contextualised introduction.

\section{Problem statement}

The services of academic libraries in the information and knowledge society have developed significantly to meet the anticipated needs and provision of services to its clients, through the application of knowledge management processes (Griffiths \& Pantry 2003; Koloniari \& Fassoulis 2017; Rowley 2001; Mavodza \& Ngulube 2011:31; Singh 2007). Knowledge management processes, such as the creation, sharing, organisation and storage, enable academic libraries to effectively solve problems and improve their decisionmaking capabilities (Hoq \& Akter 2012:92). According to Roy (2015:23), knowledge management in academic libraries is essential for the promotion of innovation, for communication and for improving the quality of services. Kaane (2009) posits that knowledge management in academic libraries results in improving services through the creation of an organisational culture that supports the sharing of knowledge and expertise, changing values, the use of intellectual assets and restructuring the functions, roles and responsibilities. As a staff member of St. Paul's academic library, the researcher observed that there was limited knowledge sharing, knowledge creation, knowledge retention, knowledge transfer, knowledge storage and application in the library. The library lacked a formal knowledge management structure that enables library staff to participate in knowledge management processes. This had taken a toll on the efficient and effective function of St. Paul's University Library. Against this backdrop, this article investigates knowledge management processes at St Paul's University Library in Kenya.

\section{Research objective}

The following are the objectives of this article:

- To determine knowledge management awareness at St Paul's University Library.

- To establish how knowledge is created at St Paul's University Library.

- To establish how knowledge is organised at St Paul's University Library.

- To determine how knowledge is shared and/or transferred at St Paul's University Library.

- To establish how knowledge is retained at St Paul's University Library.

This article seeks to answer the following questions:

- What is the understanding of knowledge management awareness at St Paul's University?

- How is knowledge created at St Paul's University Library?

- How is knowledge organised at St Paul's University Library?

- How is knowledge shared and/or transferred at St Paul's University Library?

- How is knowledge retained at St Paul's University Library?

\section{Literature review}

This section presents an overview of the process-based perspective of knowledge management, knowledge management processes in academic libraries, knowledge management awareness, knowledge creation, knowledge organisation, knowledge sharing and/or transfer, knowledge storage and knowledge retention.

\section{Process-based perspective of knowledge management}

There is no single definition of knowledge management; different authors define it according to their context and purpose. In view of the process perspective of this article, knowledge management is defined as the effective management of the sharing and retention of information in organisations and the use of management techniques to fully optimise the acquisition, dissemination and use of knowledge (Awad \& Ghaziri 2007). Seleim and Khalil (2007:37) classify the knowledge management processes into five dimensions that include knowledge acquisition, knowledge creation, knowledge transfer, knowledge organisation and knowledge application. Galagan (1997:26) proposed a knowledge management process that includes gathering new knowledge; accessing knowledge from external sources; representing knowledge in documents, databases and software; embedding knowledge processes, products or services; transferring existing knowledge around an organisation; using accessible knowledge in decision-making; facilitating knowledge growth through culture and incentives; and measuring the value of knowledge management. Nonaka (1991:96) views knowledge management processes as turning data into information and transforming information into 
knowledge in a cyclic process that involves various activities such as knowledge creation, knowledge codification, knowledge transfer and knowledge application.

The process-oriented perspective is perceived as a dynamic human process of justifying personal beliefs as part of an aspiration for the truth (Nonaka \& Takeuchi 1995:70). This implies a continuous and dynamic adaptation to 'real life'. From the process-oriented epistemology, knowledge creation and sharing are considered to be a continuous process where knowledge is transformed between tacit and explicit knowledge and between people and technology. The point of departure is the socialisation, externalisation, combination and internalisation (SECI) model of Nonaka and Takeuchi (1995:70). According to the SECI model, organisational knowledge comprises continuous and dynamic interactions between tacit and explicit knowledge. During socialisation, individuals share their experiences, thereby creating tacit knowledge such as mental models and technical skills. Through externalisation, tacit knowledge becomes explicit knowledge, 'taking the shape of metaphors, analogies, concepts, hypotheses or models' (Nonaka \& Takeuchi 1995:64). Combination is the conversion of explicit knowledge to explicit knowledge in order to create new explicit knowledge. Internalisation is the process of converting explicit knowledge into tacit knowledge. These models are also referred to as the knowledge conversion processes because the knowledge management processes are considered as the whole range of activities that support the conversion of tacit to explicit knowledge.

\section{Knowledge management processes in academic libraries}

Drawing from the process perspective, knowledge management processes in academic libraries for the purpose of this article revolve around knowledge acquisition, organisation, dissemination, creation, storage, sharing and/ or transfer and retention.

The term 'acquisition' refers to the ability to identify, acquire and accumulate knowledge that is essential for a firm's operations (Mills \& Smith 2011:156). Maponya (2004) suggested that knowledge in academic libraries could be acquired through establishing links or networking with other libraries and with institutions of all kinds, attending training programmes, conferences, seminars and workshops, and buying knowledge products or resources in the form of manuals, blueprints and research reports.

According to Hjørland (2005), knowledge organisation is defined as being concerned with constructing and evaluating semantic tools for information retrieval (IR). Knowledge organisation is specifically concerned with activities such as indexing, abstracting and classifying bibliographical items within libraries, databases, archives and so on. Hjørland (2008) posits that knowledge organisation investigates the nature and quality of knowledge organisation processes as performed by information specialists and computer algorithms, and the structure and function of knowledge organisation systems. The role of knowledge organisation systems is to organise documents, representations of documents and concepts. This process usually results in the creation of knowledge products and services targeted at satisfying the escalating needs of users (Holm 2001). Some of these knowledge products in academic libraries include lecturers' profiles, databases of experts and users' profiles (Todd \& Southon 2001).

Knowledge in the library can be disseminated through a variety of knowledge assets such as a library alert system, library mailing lists, and information and communication technologies (ICT) (Choo 2000; Rufai \& Seliaman 2004). Kim (2004) noted that librarians should be able to extract, filter and disseminate external knowledge. Knowledge creation results from a process that encompasses communication or teamwork between individuals (Maponya 2004:14). From the library's perspective, knowledge creation implies participating more in user's reading and studying by identifying information needs. To succeed, academic library services must link with the university's academic programme or curricula. Academic libraries can become part of the knowledge creation process through participating in the teaching and research activities of the university (Tang 1998). Academic librarians can become part of the knowledge creation process by participating in the teaching and research activities of the university. Therefore, knowledge creation in this context should involve all the management effort through which the academic libraries consciously strive to acquire competencies that it does not have, both internally and externally (Tang 1998).

Knowledge storage is the process of storing the organised knowledge in organisational repositories for preservation and other multiple uses through the application of a number of retrieval tools and techniques. After obtaining the required knowledge, it is expected to be coded and recorded for easy access (Kiessling et al. 2009:421).

Knowledge sharing or transfer is used interchangeably in this article and involves the exchange of information and knowledge from one source to another through a person, group or organisation (Fugate, Theodore \& Mentzer 2009:249; Lee, Lee \& Kang 2005:481; Liao \& Wu 2009:65). Knowledge sharing in academic libraries is critical to academic performance (Daud, Abdul \& Hamid 2006).

Knowledge retention is the capture of critical knowledge and expertise that is at risk of loss when an employee leaves an organisation (Dan 2008; Kim 2005). Gupta and Govindarajan (2000:13) posit that the major aim of knowledge retention is to maintain the knowledge base of the organisation. Knowledge retention is important as academic libraries are at great risk because of the possibility of losing knowledge held by individuals or a group that interacts within an organisation or when they are about to leave the organisation (Conrad \& Newman 2000). Knowledge retention could be achieved through documentation and integrating knowledge back into the organisation with special emphasis on retaining best practices (Wamundila, Ngulube \& Levy 2011). 


\section{Research methodology}

This article employed a qualitative research approach and a case study design. The qualitative approach enabled the researcher to establish the relationship between the knowledge management processes and their effectiveness at St. Paul's university library. The case study design provided meaningful face-value credibility to unravel the concept of knowledge management and gain deep insights into knowledge management processes in the academic library. The target population was 50 (10 library management committee staff members, 20 lecturers and 20 librarians). These three groups were purposively selected as the target population because they play a key role in knowledge management enhancement at St Paul's University Library. Face-to-face interviews were conducted with all participants based on their pre-determined availability. Out of the 50 target population, only 32 were successfully interviewed to the point of saturation. Data collected were analysed using content analysis.

\section{Knowledge management awareness at St Paul's University}

The first objective of this article was to establish the understanding of knowledge management awareness at St Paul's University Library. The findings below revealed the understanding of the concept of knowledge management by most participants with a few indicating ignorance and the need for training in knowledge management:

'Knowledge management is the process of sharing, capturing and transferring information to library users.' (Participant 1, librarian, male)

'Knowledge is an information system that enables the creation, storage and retrieval of information in the library.' (Participant 2, librarian, male)

'Knowledge management is process of utilising knowledge in the library.' (Participant 3, librarian, female)

'I have heard of knowledge management and to some extent have read about it.' (Participant 8 , librarian, male)

'We don't know what knowledge management is about, it is a new concept, we have not heard about it.' (Participant 10, librarian, female)

'We need training and more education to understand what knowledge management is all about.' (Participant 6, librarian, female)

Given that the participants were drawn from three different groups, it is apparent that the understanding of knowledge management was mostly among the senior management staff. The literature reveals a lack of understanding of knowledge management concepts and their benefits by librarians in academic libraries who tend to misinterpret them as information management or content management (Nazim 2013; Roknuzzaman \& Umemoto's 2009). The levels of understanding of knowledge management concepts among librarians are varied, and most of them understand knowledge management as the management of information resources, services and systems using technology or specific processes for the capture and use of explicit knowledge, rather than sharing and using tacit knowledge (Nazim 2013).

\section{How knowledge is created at St Paul's University Library}

The second objective was to identify how knowledge was created at St Paul's University Library. The findings revealed that knowledge was created through formal and informal meetings, in-house workshops, seminars and networking with other academic intuitions. Collaboration, training, teaching and research were also recognised as forms of knowledge creation. Knowledge was also created independently without external input from other parties, such as a faculty. There were no mentorship programmes in place. The lack of any formal policy for creating knowledge and also the lack of a succession plan were evident in the participant's thoughts presented below:

'We acquire knowledge through reading literature, through formal and informal meetings.' (Participant 8 , librarian, male)

'We extract structure and organise knowledge from colleagues who are experts in different fields.' (Participant 3, librarian, female)

'We attend in-house training and workshops to improve and acquire new knowledge and capabilities.' (Participant 4, librarian, male)

'There is no policy on creation of knowledge in our department and this creates a problem because anyone can just randomly do as they like with regard to knowledge creation.' (Participant 12, librarian, female)

'The library does create knowledge independently to some level and also collaborates with faculty to create knowledge.' (Participant 13, librarian, male)

'The academic staffs are the ones involved in knowledge creation, through teaching and through research work.' (Participant 14, librarian, male)

'Mentoring was largely viewed as a way of continuous improvement but without formal arrangement to see its implementation.' (Participant 16, librarian, female)

'Most knowledge is acquired through seminars and networking with other libraries and institutions.' (Participant 32, library management, female)

'Succession plan in departments did not exist.' (Participant 18, librarian, male)

'The organisation sponsors its employees for further education to acquire degrees at local and regional universities.' (Participant 31, library management, male)

'In most cases, employees attend in-house training and workshops to improve and acquire new knowledge and capabilities.' (Participant 30, library management, female)

'It is easy to acquire knowledge especially since most of the staff members are still progressing in their studies hence knowledge on their various fields is on their fingertips.' (Participant 9, senior management, male)

'The library subscribes to listservs and online CoPs.' (Participant 29 , library management, female)

It was evident from the above findings that research work, training, workshops, seminars and networking with other institutions were means of knowledge creation in the library. This concurs with Maponya's (2004) and Ongus et al.'s (2015) findings that libraries had used partnership with other 
libraries to acquire knowledge to sharpen their skills in this dynamic information technology environment. The findings further revealed the absence of formal mechanisms for creating knowledge such as knowledge mapping, mentoring, storytelling forums, use of focus groups and benchmarking. The library also lacks written policies that would help set standards to motivate staff to create, share and retain knowledge. Sagsan (2007) asserts that the purpose of a university library is to create knowledge through social communication networks, formal and informal; teamwork; community of practices; organisational learning; and formal communications technology with individual, group or departmental institutions. Reio and Wiswell (2000) further elaborate that individuals may rely on different learning channels to obtain explicit and tacit knowledge. Jantz (2001) further suggests that knowledge acquisition could be enhanced by providing training opportunities for staff.

\section{How knowledge is organised at St Paul's University Library}

The third objective of this article was to identify how knowledge was organised at St Paul's University Library. It was clear from findings that although the library was automated there was no proper system in place to organise knowledge. Participants noted the use of cataloguing and classification to organise knowledge, while abstracting and indexing were not fully exploited. They did not consider an institutional repository to be in existence, although the majority of the academic staff and non-academic staff were doing research work and publishing their work. This could be attributed to the lack of awareness and lack of training of its use as reflected in some of the responses below:

'Knowledge organisation is the responsibility of the library.' (Participant 12, lecturer, male)

'St Paul's Library is automated and is using Koha [software]; library database for knowledge organisation.' (Participant 18, librarian, male)

'The library uses Open Access Catalogue (OPAC) to organise knowledge.' (Participant 15, librarian, female)

'St Paul's University Library doesn't have effective processes for organising knowledge.' (Participant 1, librarian, male)

'They had no idea of how knowledge was gathered, organised in the library.' (Participant 2, librarian, male)

A question on whether there was an institutional repository accessible at the library, revealed the following responses:

'There is an institutional repository in the library though it is yet to grow and be used sufficiently'. 'It was still being developed.' (Participant 3, librarian, female)

'The institution should invest heavily in the library in terms of learning and teaching resources hence becoming the central place for knowledge.' (Participant 4, librarian, female)

Another participant mentioned that there was no institutional repository in place:

'I am not aware of any institutional repository in the library.' (Participant 1, librarian, male)
'Staff and students are not well trained on technologies such as an institutional repository.' (Participant 5, librarian, female)

'Materials in this library's repository is currently limited to library resources, past papers, institutional conference proceedings and annual reports.' (Participant 1, librarian, male)

Hjørland (2008:80) acknowledged that knowledge organisation is about activities such as document description, indexing and classification performed in libraries, bibliographical databases, archives and other kinds of 'memory intuitions' by librarians, archivists, information specialists, subject specialists, as well as by computer algorithms and laymen. Knowledge classification and codification are important for IR and usage. Galagan (1997) emphasises the need for knowledge to be captured and stored in the organisation's repositories such as databases, documents and software and embedding it into processes, products and services, thus transferring the existing knowledge around in the organisation. Brannin (2003) asserts that an institutional repository is vital in all academic libraries, as it promotes research, learning and education.

\section{How knowledge is shared at St Paul's University Library}

The fourth objective of this article was to identify how knowledge was shared and transferred at St Paul's University Library. It is clear from the responses below that although knowledge sharing was encouraged and happens at St. Paul's University Library to a large extent, the culture of knowledge sharing among colleagues remained a challenge. Academic retreats, workshops, monthly training, conferences and networking with other academic libraries were seen as sporadic events for knowledge sharing. The findings are evident in the response below.

'Our library networks with other academic and non-academic libraries so that we can exchange information that is important for our library patrons and also staff.' (Participant 30, librarian, female)

'Our librarian normally organises library retreats at least every year and departmental meetings every semester whereby we share knowledge pertaining to our careers.' (Participant 1, librarian, male)

'Academic workshops are organised once in a while that enhance knowledge sharing.' (Participant 2, librarian, male)

'There is no sharing of knowledge between departments. Knowledge sharing was not encouraged and not supported.' (Participant 10, librarian, female)

The following are some positive responses concerning knowledge sharing:

'There is training at the end of every month where an employee is given an opportunity to participate by making a presentation on a given topic.' (Participant 28, library management, male)

'It is encouraged by enabling employees to attend workshops and conferences.' (Participant 16, librarian, male)

'We train users on how to use online resources.' (Participant 5, librarian, female) 
'Our library network with other academic and non-academic libraries so that we can exchange information that is important for our library patrons and also staff.' (Participant 4, librarian, male)

'Our librarian normally organise library retreats at least once every year and departmental meetings every semester whereby we share knowledge pertaining to our careers.' (Participant 7, librarian, female)

In order to further understand knowledge sharing, a question was asked to determine the measures the library had put in place to encourage a culture of knowledge sharing. The following responses were noted:

'New information is communicated to the staff in the library regularly through meetings, emails and university memos.' (Participant 8, librarian, male)

'We usually hold monthly seminars/workshops in the library.' (Participant 32, librarian, female)

'The staff don't want to share information with others fearing that once they share they will be out-shined by their peers.' (Participant 14, librarian, male)

There were, however, those that were either not sure or did not think that knowledge sharing was encouraged and supported. Additionally, some participants were of the opinion that essential knowledge that they required to execute their duties was not readily available in the library. This is definitely a pointer to an area that may require improvement, through techniques such as the introduction of incentives and enhancement of library training, as suggested by Hussock (2009:30). According to Jones, Cline and Ryan (2006:414), factors that promote knowledge sharing included training of users on how to access information through the use of e-resources, networking with other academic libraries and attending training every month when employees are given opportunities to make presentations. Also, strengthening the culture of trust and top management support lead to a more positive attitude towards knowledge sharing and ultimately a better chance of success for knowledge management in an academic library (Marouf 2017).

\section{How knowledge is retained at St Paul's University Library}

The fifth objective of this article was to identify how knowledge was retained at St Paul's University Library. The findings indicated that the library had not established a proper knowledge management strategy for the retention of personalised knowledge in the library. Knowledge existed only in procedures, manuals and computers and not in a central location. Additionally, participants were largely unaware of the processes of capturing and sharing knowledge. They indeed mentioned that the expertise of the retired and resigned staff had not been captured elsewhere, although it should be noted that the sampled participants for this article did not include employees who worked in St Paul's University human resource unit. The library also did not have a knowledge retention strategy and policy. The above findings are evident in the responses below:

'Knowledge was rarely documented and rarely passed on hence a new person comes in with a totally different strategy.' (Participant 5, librarian, female)
'Knowledge retention policy does not exist at St Paul's University Library.' (Participant 20, librarian, female)

'Knowledge retention policies and practices are vague.' (Participant 21, librarian, male)

'There should be a central place where procedures are kept so that they can be shared.' (Participant 23, librarian, male)

'We are not sure of any knowledge retention policy.' (Participant 24 , librarian, female)

'Knowledge existed in procedure manuals and on job descriptions.' (Participant 25, librarian, male)

'We record our own experiences, for the benefit of our educational or work-related programs in which we are involved.' (Participant 26, librarian, female)

'Knowledge is available in our PCs computers in our various departments for use.' (Participant 1, librarian, male)

'The knowledge that we need is found only among the knowledge experts and not in a central location.' (Participant 27, librarian, male)

'Knowledge was not really retained when an employee exited unless the individuals made the effort to share it before leaving.' (Participant 1, librarian, male)

'Most staff left without sharing their knowledge and it was a big challenge for the institution'. 'Knowledge was rarely documented and rarely passed on hence a new person comes in with a totally different strategy.' (Participant 2, librarian, male)

'The library practice of job rotation was limited.' (Participant 1 , librarian, male)

Wamundila and Ngulube (2011) posit that knowledge can be retained in an organisation through strategies such as education, training, establishing communities of practice and professional networks, documenting the processes and the use of advanced technology to capture work processes. Galagan (1997) advocates the need for knowledge gained and built-up through years of experience to be captured and stored in the organisation's repositories such as databases, documents and software, and embedding it into processes, products and services. Holtshouse (2009) further posits that valuable organisational know-how might be captured using resources such as communities of practice, professional networks, documentation processes and work processes.

Inmon, O'Neil and Fryman (2008) mentioned different sources of knowledge retention as information: emails, contracts, proposals, reports, copyrights, work processes, procedures, products and individual employees with mental knowledge. In addition, Dubin (2005), Jain (2009), Poole and Shenan (2006) and Dewah (2011) identified communities of practice, repositories, mentoring and apprenticeship programmes as approaches to knowledge retention.

\section{Recommendations}

The article recommends that knowledge management processes should be formally incorporated at the academic library in Kenya, as this will increase the effectiveness and the efficiency of the library. A formal knowledge management process may be realised through an 
institutionalised written knowledge management policy that should seek to facilitate the acquisition, sharing, transfer, capture, storage, utilisation and retention of knowledge of the internal staff. Top management support is crucial in implementing this policy.

The knowledge management policy should establish a formal mechanism for the identifying, organising, storing, creating, sharing, utilising and retention of knowledge of expert employees at St Paul's University. Knowledge mapping, mentoring, use of storytelling forums, focus groups' research work and output, acquisitions, seminars and networking, and benchmarking are some of the techniques that will facilitate the knowledge management processes in this library. Participants suggested the documentation process, recognition and implementing of reward structure, interviewing retirees, library procedures or processes manuals, and job rotation as some procedures to consider in enhancing knowledge retention.

The knowledge management policy should recommend the adoption and use of technologies in St Paul's academic library for different knowledge management processes. Among these technologies are video conferencing, social media tools, wikis, and D-space and expert systems. A vast amount of knowledge resides in the heads of experts, which could remain unused if not tapped. The use of knowledge 'expert systems' is one of the ways in which knowledge may be acquired (Davenport \& Prusak 1998; Koenig \& Srikantaiah 2000). The knowledge management policy should also highlight the need for an institutional repository and the importance on how and when to utilise a repository.

The knowledge management policy should make provision for ICT training for knowledge workers in academic libraries and their parent organisations. Training programmes should be comprehensive. Besides ICT training, the knowledge management policy should establish training programmes for staff to enhance their understanding of the different knowledge management processes. Rigorous training programmes and workshops should be developed by the library management committee for faculties, library staff and other knowledge stakeholders on the discipline of knowledge management. Training programmes should specifically target knowledge workers who are clueless regarding the knowledge management processes. Knowledge management training will in turn result in knowledge acquisition and thus increase the level of staff expertise. Besides the suggested training programmes, academic libraries should make provision for feedback mechanisms and rewards systems based on the effective and efficient use of technology.

\section{Conclusion}

The aim of this article was to establish the knowledge management process at St Paul's University Library. The findings revealed that the library has some understanding of knowledge management, and the different knowledge management processes are in existence, although not sufficiently explored. Based on the findings, it was recommended that knowledge management processes should be formally incorporated at academic libraries in Kenya as this will increase the effectiveness and efficiency of the academic libraries. A formal knowledge management process may be realised by developing an institutionalised written knowledge management policy. A written policy would help set standards that will motivate staff to create, share and retain the knowledge. In addition, incentives should be given to workers for compliance to the knowledge management policies.

\section{Acknowledgements}

The authors would like to thank the University of South Africa for the support provided to conduct this study.

\section{Competing interests}

The authors declare that they have no financial or personal relationships that may have inappropriately influenced them in writing this article.

\section{Authors' contribution}

Both authors equally contributed to the writing of this article.

\section{References}

Anduvare, E.M., 2015, 'Developing a knowledge management strategy for the Marist International University College', Nairobi-Kenya, Research Theses, University of South Africa, Pretoria, viewed 11 August 2017, from http://hdl.handle. net $/ 10500 / 18310$

Awad, E.M. \& Ghaziri, H.M., 2007, Knowledge management, Pearson Education, New Delhi.

Branin, J., 2003, 'Knowledge management in academic libraries: Building the knowledge bank at the Ohio State University', Journal of Library Administration 39(4), 41-56. https://doi.org/10.1300/J111v39n04_05

Choo, C., 2000, The knowing organisation: How organisations use information to construct meaning, Oxford University Press, Oxford.

Conrad, K.W. \& Newman, B.D., 2000, 'A framework for characterizing knowledge management: Methods, practices, and technologies', in Proceedings of the third International Conference on practical aspects of knowledge management, Basel, Switzerland, October 29-30, 2000, vol. 16, pp. 1-11.

Dan, K., 2008, Knowledge retention, viewed 28 September 2017, from http://it. toolbox.com/wiki/index.php/Knowledge_Retention

Daud, S. \& Abdul-Hamid, H., 2006, 'Successful knowledge sharing in private higher institutions' education: Factors and barriers', Paper presented from 6-8 June at the Knowledge Management International Conference and Exhibition, K.L., Malaysia, Unpublished.

Davenport, T.H. \& Prusak, L., 1998, Working knowledge: Managing what your organisation knows, Harvard business School Press, Boston, MA.

Dewah, P., 2011, Knowledge retention strategies in selected Southern African public Broadcasting Corporations, University of Fort Hare, viewed 25 July 2017, from http://hdl.handle.net/10353/438

Dubin, M., 2005, Creating an environment in the law firms where knowledge management will work, viewed 02 August 2017, from http://www.http/www. searchwarp.com/html

Fugate, B.S., Theodore, P.S. \& Mentzer, J.T., 2009, 'Linking improved knowledge management to operational and organisational performance', Journal of Operations Management 27, 247-264. https://doi.org/10.1016/j.jom. 2008.09.003

Galagan, P., 1997, 'Smart companies', Knowledge Management, Training and Development 51(12), 20-25.

Gichuhi, Z.P., 2015, 'Determinants of effective knowledge management practices in selected university libraries in Nairobi-Kenya and Kiambu counties, Kenya', Research Theses, viewed 04 June 2018, from http://www.ir-library.ku.ac.ke

Griffiths, P. \& Pantry, S., 2003, 'Librarians or knowledge managers? What's in a name, or is there a real difference?', Business Information Review 20(2), 102-109. https://doi.org/10.1177/0266382103202011

Gupta, A.K. \& Govindarajan, V., 2000, 'Knowledge flows within multinational corporations', Strategic Management Journal 1(21), 473-496. https://doi. org/10.1002/(SICI)1097-0266(200004)21:4\%3C473::AID-SMJ84\%3E3.0.CO;2-I 
Hjørland, B., 2005, Lifeboat for knowledge organization, viewed 25 May 2018, from http://www.db.dk/bh/lifeboat_ko/home.htm

Hjørland, B., 2008, 'What is knowledge organisation (KO)?', Knowledge Organisation $35(2 / 3), 86-101$

Holm, J., 2001, 'Capturing the spirit of knowledge management', Paper presented a the American Conference on Information Systems, Boston, MA, 10-15th August.

Holtshouse, D., 2009, 'The future of knowledge workers', KM World 18(8), 1-30, viewed 05 November 2017, from www.kmworld.com/Articles/.../The-future-of knowledge-workers-Part-1-55779.aspx

Hoq, K.M.G. \& Akter, R., 2012, 'Knowledge management in universities: Role of knowledge workers', Bangladesh Journal of Library and Information Science 2(1) 92-103. https://doi.org/10.3329/bjlis.v2i1.12925

Hussock, J., 2009, 'Defining a framework for knowledge sharing in a dynamic sales oriented organisation', Master thesis, Dublin Institute of Technology, Dublin.

Inmon, W.H., O’Neil, B. \& Fryman, L., 2008, Business metadata, Morgan Kaufmann, Burlington, $\mathrm{MA}$.

Islam, M.A., Agarwal, N.K. \& Ikeda, M., 2015, 'Knowledge management for service innovation in academic libraries: A qualitative study', Library Management 36(1/2), 40-57. https://doi.org/10.1108/LM-08-2014-0098

Islam, S., Siddike, A.K., Nowrin, S. \& Naznin, S., 2015, 'Usage and application of knowledge management for improving library and information services in Bangladesh', Journa of Information and Knowledge Management 12(4), viewed 05 May 2018, from https://www.worldscientific.com/doi/abs/10.1142/S0219649213500342

Jain, P., 2007, 'An empirical study of knowledge management in academic libraries in East and Southern Africa', Library Review 56(5), 377-392, viewed 10 August 2017 from http://iafor.org/archives/offprints/acah2012-offprints/ACAH20120185.pdf

Jain, P., 2009, 'Knowledge management in e-government', Journal of Knowledge Management Practice 10(4), 1-10.

Jantz, R., 2001, 'Knowledge management in academic libraries: Special tools and processes to support information professionals', Reference Services Review 29(1) 33-39. https://doi.org/10.1108/00907320110366778

Jones, M.C., Cline, M. \& Ryan, S., 2006, 'Exploring knowledge sharing in ERP implementation: An organizational culture framework', Decision Support System 41(2), 411-434. https://doi.org/10.1016/j.dss.2004.06.017

Kaane, S., 2009, Knowledge management in libraryies: An introduction, viewed 15 November 2017, from http://library.ifla.org/1223/1/180-jain-en.pdf

Kiessling, T.S., Richey, R.G., Meng, J. \& Dabic, M., 2009, 'Exploring knowledge management to organisational performance outcomes in a transitional economy' Journal of World Business 44, 421-433. https://doi.org/10.1016/j.jwb.2008.11.006

Kim, M.P., 2005, Knowledge retention enhances performance-based management viewed 29 September 2017, from http://www.dcma.mil

Kim, S., 2004, Organisational factors affecting knowledge sharing capabilities in government: An empirical study, viewed 26 October 2017, from http://dl.ifip.org/ government: An empirical study, viewed 26 /

Koenig, M.D. \& Srikantaiah, T.K., 2000, 'The evolution of knowledge management', in K. Srikantaiah \& M.E.D. Koenig (eds.), Knowledge Management for the Information Professional, Information Today Inc., pp. 37-61, Medford, NJ.

Koloniari, M. \& Fassoulis, K., 2017, 'Knowledge management perception in academic libraries', Journal of Academic Librarianship 43(2), 135-142. https://doi. org/10.1016/j.acalib.2016.11.006

Lee, K.C., Lee, S. \& Kang, I.W., 2005, 'KMPI: Measuring knowledge management performance', Information and Management 42, 469-482. https://doi. org/10.1016/j.im.2004.02.003

Liao, S.H. \& Wu, C.C., 2009, 'The relationship among knowledge management, organisational learning and organisational performance', International Journal of Business and Management 4(4), 64-76. https://doi.org/10.5539/ijbm.v4n4p64

Madge, O.L., 2017, 'Current stage of application of the knowledge management process in Romanian academic libraries', The 13th International Scientific
Conference eLearning and Software for Education, Bucharest, Romania, April 27Conference eLearning and Software for Education, Bucharest, Rom
28, 2017, pp. 83-88. https://doi.org/10.12753/2066-026X-18-185

Maponya, P.M., 2004, Knowledge management practices in academic libraries, A case study of the University of Natal, Pietermaritzburg libraries, South Africa.

Marouf, L., 2017, 'Are academic libraries ready for knowledge management?', Electronic Library 35(1), 137-151. https://doi.org/10.1108/EL-01-2016-0008

Mavodza, J. \& Ngulube, P., 2011, Exploring the use of knowledge managemen practices in an, Academic library in a changing information environment, viewed 12 April 2017, from http://sajlis.journals.ac.za/pub/article/viewFile/63/55

Mills, A. \& Smith, T., 2011, 'Knowledge management and organisational performance, a decomposed view', Journal of Knowledge Management 15(1), 156-171. https:// doi.org/10.1108/13673271111108756

Mosoti, Z. \& Masheska, B., 2010, 'Knowledge management: The case for Kenya', The Journal of language, Technology and Entrepreneurship in Africa 2(1), viewed 27 March 2017, from http://www.ajol.info/index.php//jolte/article/viewfile/51994/40629

Nazim, M.M.B., 2013, 'Librarians' perceptions of knowledge management in developing countries: A case with Indian academic libraries', International Information and Library Review 45(1-2), 63-76.
Nonaka, I., 1991, 'The knowledge-creating company', Harvard Business Review, November-December, pp. 96-104.

Nonaka, I. \& Takeuchi, H., 1995, The knowledge creating company: How the Japanese companies create the dynamics of innovation, Oxford University Press, New York.

Nyakenyanya, N.A., 2013, 'Effects of knowledge management practices on organizational performance: A case study of selected campuses of Kisii University, Kenya', Masters Dissertation, Kisii University, viewed 19 December 2017, from http://library.kisiiuniversity.ac.ke:8080/xmlui/handle/123456789/46

Nyalwal, G., 2015, 'Implementing knowledge Management practices in University ibraries In Kenya', in 1st Regional Conference on Knowledge management, viewed 06 June 2018, from https://profiles.uonbi.ac.ke/gnyalwal/

Odero, D.J.N. \& Ngeno, E., 2009, 'Integrating knowledge sharing practices in public University libraries: A case for Kenya', East African Journal of Information Sciences (EAJIS), viewed 12 June 2017, from https://www.ajol.info/index.php/eajsci

Ogalo, S.A., 2012, 'Knowledge management practices in university libraries in Kenya', Research Thesis, Nairobi-Kenya, viewed 11 July 2017, from http://erepo.usiu.ac. $\mathrm{ke} / \mathrm{handle} / 11732 / 2982$

Ongus, R.W., Lionel, K., Mbugua, P. \& Nyamboga, C.M., 2015, 'Standards and practices of knowledge management in academic libraries: Ekiti State University in perspective', Information Studies 21(1), 19-32. Viewed 12 May2017 from https:// perspective', Information Studies 21(1), 19-
doi.org/10.5958/0976-1934.2015.00002.6

Poole, D. \& Sheehan, T., 2006, 'Strategies for managing the global brain drain', Knowledge Management Review 9(2), 22-25.

Rao, S.S., 2016, 'Use of knowledge management tools and techniques in academic libraries in India: A study', SRELS Journal of Information Management 53(5), $1-8$

Reio, T.G. \& Wiswell, A., 2000, 'Field investigation of the relationship among adult curiosity, workplace learning and job performance', Human Resource Development Quarterly 11, 5-30. https://doi.org/10.1002/1532-1096(200021)11:1\%3C5::AIDHRDQ2\%3E3.0.CO;2-A

Roknuzzaman, M. \& Umemoto, K., 2009, 'How library professionals view knowledge management in libraries: A qualitative study', Library Management 30(8/9), 643656. https://doi.org/10.1108/01435120911006593

Rowley, J., 2001, 'Knowledge management in pursuit of learning: The learning with knowledge cycle', Journal of Information Science 27(4), 227-237. https://doi. org/10.1177/016555150102700406

Roy, H., 2015, 'Knowledge management and the role of academic libraries', International Journal of Research in Library Science 1(1), 20-25.

Rufai, R. \& Seliaman, M.E., 2004, Towards a knowledge management model for Universities, viewed 29 May 2017, from http://ickm.upm.edu.my/parallel\%20 Universities, viewed 29 May 2017, from http://ickm.upm.edu.my/parallel\%20
session\%202/Raimi\%20and\%20SeliamanTowards\%20a\%20km20model\%20 for\%20Universities

Sagsan, M., 2007, 'Knowledge management from practice to discipline: A field study', AID TODAIE'S Review of Public Administration 1(4), 123-157.

Seleim, A. \& Khalil, O., 2007, 'Knowledge management and organisational performance in the Egyptian software firms', International Journal of Knowledge Management 3(4), 37-66. https://doi.org/10.4018/ijkm.2007100103

Singh, S.P., 2007, 'What are we managing - knowledge or information?', VINE: The Journal of Information and Knowledge Management Systems 37(2), 169-179. https://doi.org/10.1108/03055720710759946

Tang, H.K., 1998, 'An integrative model of innovation in organisations', Technovation 18(5), 297-309. https://doi.org/10.1016/S0166-4972(98)00009-1

Thanuskodi, S., 2010, 'Knowledge management in academic libraries: An overview', in 6th International Conference on Webometrics, Informetrics and Scientometrics and Eleventh COLLNET Meeting, October 19-22, University of Mysore, viewed 22 November 2017, from http://eprints.rclis.org/25405/1/IILR-D-13-00018R2\%20 $\% 283 \% 29$.pdf

Todd, R. \& Southon, G., 2001, 'Library and information professionals and knowledge management; conceptions, challenges and conflicts', Australian Library and Information Association 50(3), viewed 16 Septembeter 2017, from http:// kmeducationhub.de/library-and-information-professionals-and-knowledgemanagement/

Wamalwa, L.W. \& Omallah, B.G., 2016, 'Knowledge management practices and performance of academic libraries: A case of Mount Kenya University, Kigal Campus Library', viewed 20 October 2017, from https://erepository.mku.ac.ke/ handle/123456789/4079

Wamundila, S., 2008, 'Developing guidelines for a knowledge management policy to enhance knowledge retention at the University of Zambia', Thesis (Masters) Pretoria, University of South Africa, viewed 21 May 2017, from http://www. academia.edu/1762104/Developing-guidelines-for-a-knowledgemanagement-policy-to-enhance-knowledge-retention-at-the-University-ofZambia

Wamundila, S. \& Ngulube, P., 2011, 'Enhancing knowledge retention in higher education: A case of the University of Zambia', South African Journal of Information Management 13(1), 439-448. https://doi.org/10.4102/sajim.v13i1.439

Wen, S., 2005, 'Implementing knowledge management in academic libraries: A pragmatic approach', Ann Arbor 1001, 109-1205. 